\title{
ANÁLISE SOBRE FORMAS ESTRATÉGICAS NOS DISCURSOS FASCISTAS E DO INTEGRALISMO DE PLÍNIO SALGADO
}

\section{Felipe Azevedo Cazetta*}

RESUMO: Este artigo vem com o objetivo de traçar comparações entre os fascismos e o integralismo, a partir da utilização do totalitarismo como uma das formas de ascensão ao poder, por ambos os movimentos, tanto o europeu quanto o brasileiro. Entretanto, a pesquisa vislumbra tecer não só similaridades mas, examinar as divergências entre as balizas abordadas, através da observação do corpo teórico do Sigma.

PALAVRAS-CHAVE: Integralismo, Fascismo, Autoritarismo.

ABSTRACT: This article is aiming to draw comparisons between fascism and integralism, from the use of totalitarianism as a way of coming to power, used by both movements, both European and Brazilian. However, the research looks make not only similarities but to examine the differences between the tags addressed by observing the Sigma theoretical body.

KEY-WORDS: Integralism, Fascism, Authoritarianism.

\footnotetext{
* Mestrando em História pelo Programa de pós-Graduação da Universidade Federal de Juiz de Fora, Bolsista pela CAPES desde março de 2010.
} 
Este artigo tem como objetivo tecer comparação entre o integralismo e os fascismos visando perceber divergências e aproximações, no intuito de relativizar o monopólio teórico do fascismo em relação às matrizes do Integralismo de Plínio Salgado em específico. Neste sentido, se observará as ideias que compuseram a ideologia integralista, sem, contudo ignorar a influência que as condições e característica do meio reproduziram nos mentores do arcabouço doutrinário que constituiu a AIB. Assim, poderei alcançar a resposta da pergunta: O Integralismo de Plínio Salgado era uma versão brasileira do fascismo?

Portanto, afirma-se a impossibilidade de "cópia" como composição nuclear central de ideias do integralismo, compreendendo ser mais exato dizer apropriação, haja vista a necessidade de adaptação de um conteúdo, caso este seja desvinculado de sua realidade original. Segundo Reinhard Bendix (1996: p. 35): "A crença na universalidade dos estágios evolutivos foi substituída pela compreensão do momentum dos eventos passados e a diversidade das estruturas sociais conduzem a diferentes caminhos de desenvolvimento, mesmo quando as mudanças de tecnologia são idênticas."

Destarte, há outras nuances que igualmente compõe o arcabouço do integralismo, e que inviabilizam a classificação do movimento chefiado por Salgado como sendo filiado ao fascismo, por mais flexível e incômodo de ser classificado que o conceito "Fascismo" venha a ser. Pretende-se demonstrar, portanto, que mesmo lançando mãos ao fascismo para construir a doutrina integralista, é necessário antes, analisar como este foi "encaixado" para consolidar o conjunto teórico do Sigma e relacionado a quais outros componentes. Para somente então concluir se o integralismo foi ou não um exotismo excêntrico em terras brasileiras.

O que mais salta aos olhos inicialmente são as concepções totalitárias que permeiam tanto fascismos quanto integralismo, sendo estas influências pela via do corporativismo, do terror e da propaganda ou pela utilização do catolicismo como prerrogativa expansionista e imperialista de visão de mundo. Tratarei então de falar sobre as relações do fascismo, do positivismo, do catolicismo e do positivismo no interior do Sigma no intuito de traçar a genealogia do integralismo, podendo desta forma se chegar a conclusão se Plínio Salgado chefiava um movimento fascista ou não.

Temáticas, Campinas, 20(39): 145-180, jan./jul. 2012 


\section{O FASCISMO E O INTEGRALISMO}

O totalitarismo é uma divisa comum ao integralismo e aos fascismos, contudo, esta forma de manifestação do poder político assume aspectos distintos mesmo sendo uma das interseções entre as duas ideologias. Enquanto no integralismo, se faz necessária a presença da figura divina no combate ao comunismo e, na perspectiva de Salgado, por conseguinte, ao liberalismo ${ }^{1}$; no fascismo italiano e no nazismo alemão, há o esforço para concorrer com a religiosidade para fundar o culto à nação e à religião cívica em primeiro lugar.

A reverência da massa ao Estado incorporado na figura do chefe, por si só seria suficiente como suporte aos fascismos para fazer frente à ameaça externa, seja ela o comunismo soviético, o imperialismo capitalista ou o fictício terror do imperialismo semita. Como esboço ilustrativo, há o relato de um autor francês que em viagem à Itália fascista, expondo suas sensações sobre aquele Estado, e sobre suas percepções em relação à religião cívica fascista:

Finalmente, como tôdas suas irmãs, a religião fascista julga possuir a verdade inteira e absoluta. Um dos lugares tenentes do Duce, Bottaï, ministro das Corporações, dizia-o ainda recentemente: "Assim como um católico não discute sua fé, também nos não discutimos os dogmas do nosso credo fascista." (ROUX, 1937: p. 111)

Fica exposto que embora a Itália fosse um país de população

\footnotetext{
1 "Mas para armar ao efeito, o marxismo diz lutar contra o capital e contra o chamado ‘imperialismo econômico’ das nações favorecidas pelo acúmulo dos meios de produção. Esse cartaz deu à batalha social um caráter de internacionalismo. Influindo no mundo político, gerou a concepção de 'direitas' e 'esquerdas', entendendo-se por 'esquerdas', tudo aquilo que favorecia o desenvolvimento da revolução, pelo que se inclui na linha do 'esquerdismo' os chamados 'reformistas', constituídos pelos liberais avançados, pelos socialistas moderados, pelos burgueses progressistas, enfim, pelos transnacionais de todos os credos políticos fundados no indiferentismo religioso ou num cristianismo de elástica transigência." SALGADO, P. Primeiro, Cristo! In. Obras Completas. v. 6. São Paulo: Editôra das Américas, 1955 p. 199.
} 
majoritariamente católica, o fascismo de Mussolini se colocava como concorrente ideológico do Vaticano justamente por causa da sensível influência que a Igreja oferecia na mentalidade da população. A disputa pela hegemonia por sectários era destinada à massificação, para a manutenção e patrocínio do terror imposto como propaganda do regime. A perspectiva conflitante entre Mussolini e o Papa não se restringia somente ao campo religioso/ideológico.

A disposição do fascismo italiano em lançar-se ao embate contra a Igreja, implicava diretamente na intenção do Estado em se tornar presente em sua amplitude burocrática. $\mathrm{O}$ anseio totalizante do corporativismo do Duce abrangia toda entidade assistencialista que se instalasse no território italiano ou atendesse aos cidadãos italianos, mesmo que no exterior. Tais instituições de apoio e auxílio social deveriam se submeter completamente ao governo fascista - algo engenhoso, pois assim o Estado desfrutava do controle da entidade sem que precisasse investir financeiramente na mesma, além do que, poderia se beneficiar com o sucesso da organização assistencialista, ou fechá-la sem maiores problemas caso fosse necessário, sem desgastes profundos para sua imagem.

Contudo, a Igreja Católica nem sempre se inclinou da forma esperada pelo regime, tendo várias de suas entidades de assistência, impedidas de operar pelo governo Mussolini. João Fábio Bertonha afirma que "A aproximação e colaboração entre as organizações católicas que trabalhavam com emigrantes italianos, e os organismos fascistas ocorreram, mas não no nível de dependência desejado pelo fascismo."(Bertonha. 1998: p. 42)

Quanto à Alemanha, o culto ao líder é dissertado por Plínio Salgado, tingido por um tom de desprezo e surpresa devido ao enlace do uso político da devoção da religião, através da adoração ao fubrer como divindade. Fato que para o líder da AIB, na Itália passou despercebido diante dos elogiosos comentários ao regime fascista de Mussolini, ao ponto de declarar, contraditoriamente que "Somos mais avançados que o fascismo, no qual, diga-se de passagem, temos muito que observar e aproveitar; (...)”. (Salgado, 1957: p. 102)

Entre o integralismo e os fascismos o enfoque que merece atenção principal quanto às convergências dos modelos de totalitarismo implantado 
na Itália, na Alemanha, e desejado pela a AIB no Brasil, a meu ver, deve ser dado "(...) ao comprometimento da personalidade do subordinado com o objetivo do líder" (Moore, 1972: p. 26). Este aspecto é ilustrativo por apontar dois pontos iniciais imprescindíveis: a caracterização essencial do totalitarismo; e a oposição deste com o autoritarismo, mesmo com ambos muitas vezes se manifestando de maneira intrínseca no momento da tomada do poder.

O Estado Burocrático Autoritário, conforme afirma Guillermo O’Donnell, é particular às sociedades capitalistas, sendo o Estado capitalista, por sua vez, originado através de relações de produção desiguais, de forma a consolidar a divisão entre elite e marginalizados, quando se tem o poder como referência (O’Donnell, 1990: pp. 24-25). Logo, o Estado Autoritário coopta como base de apoio um grupo restrito e aristocrático, com representantes provindos das elites civis e/ou militares, com a finalidade de "purgar" o poder, diante dos focos de "distúrbios" - justificando assim a restrição da composição do grupo dirigente; o totalitarismo exige a criação de um líder carismático, frente à natureza distinta do respaldo - a população amorfizada - em relação ao autoritarismo.

É crucial para a manutenção do regime totalitário, a aparência que o líder nada mais é que um "funcionário das massas que dirige", de modo a estabelecer vínculo ficcional de cumplicidade entre governo e governado ${ }^{2}$. Esta realidade paralela estabelece a identidade dissertada por Moore, entre líder e subordinados, relação que pouco ou nada importa a uma junta de governo autoritária.

Neste sentido o integralismo se insere na tendência totalitarista mesmo não conseguindo penetrar na esfera do poder central. Em Carta de Natal e de Fim de Ano é possível enxergar esta postura de onipresença do chefe. Salgado

\footnotetext{
2 "Essencialmente, o líder totalitário, é nada mais e nada menos que o funcionário das massas que dirige; (...). Como simples funcionário, pode ser substituído a qualquer momento e depende tanto do 'desejo' das massas que ele incorpora como as massas dependem dele. Sem ele, elas não teriam representação externa e não passariam de um bando amorfo; sem as massas, o líder seria uma nulidade. Hitler, que conhecia muito bem essa interdependência, exprimiu-a certa vez num discurso perante a SA: 'Tudo que vocês são, o são através de mim; tudo que eu sou, sou através de vocês." ARENDT, H. Origens do totalitarismo. Tradução de Roberto Raposo. São Paulo: Companhia das Letras, 1989. p. 375.
} 
evidencia os dois pontos ressaltados nos movimentos totalitários em geral, que são a perspectiva do líder como funcionário da massa dirigida e a dependência dos governados para com a figura do Chefe.

Não temo os inimigos nem as adversidades, porém temo os próprios integralistas. Êles, na exaltação revolucionária, poderão perder aquilo que mais procuramos, aquilo que é fundamento da nossa política: a consciência de si mesmos. E, perdendo a consciência de si mesmos, perderão o conceito da autoridade como eu quero, e a concepção de Chefe, como é necessária a uma Nação Cristã. (Salgado, 1955a: p. 290)

O terror funciona, tanto para o integralismo quanto para os fascismos como propaganda de coesão, fortalecendo vínculos existentes entre as massas e o seu líder, e o do líder para o movimento como um todo. O terror como propaganda política é importante para a movimentação e manutenção de tal cenário de instabilidade, para a organização social e imposição de uma ordem hierárquica na fusão ficcional entre líder e massa, ou líder e seu corpo burocrático estatal.

Torna-se clara a visualização da violência como meio de divulgação, para a finalidade dissertada quando se acompanha o depoimento de ex-integrantes, mesmo os pertencentes ao alto-escalão do III Reich. Como exemplo para observação, destaco a fala de Albert Speer, Ministro dos Armamentos na Alemanha Nazista:

O mundo em que movíamos, obrigava-nos à hipocrisia, às aparências, à perfídia. Diante dos rivais, jamais falávamos com franqueza; qualquer palavra podia ser desvirtuada quando transmitida a Hitler. Aquilo era um jogo felino em que se podia ganhar ou perder. Como outro qualquer, eu dedilhei também sem escrúpulos, o desafinado teclado das relações mútuas. (Speer, 1971: p. 21)

Temáticas, Campinas, 20(39): 145-180, jan./jul. 2012 
Não basta, portanto, a relação de fidelidade entre líder e governados por si só, para que o regime totalitário se consolide. Conforme visto, há a necessidade do emprego do terror constante voltado diretamente para fins políticos. É crucial para os partidos totalitários o movimento tanto físico quanto psicológico do terror. É sempre presente a idéia de conspirações, ou o mal maior que assole a estabilidade interna - seja este "mal" o liberalismo cosmopolita, o comunismo ou o perigo semita de dominação do mundo que legitime a árdua situação do momento ou o radicalismo futuro como profecia, caso o motivo de instabilidade não seja subjugado.

Desta forma, a formulação de uma utopia, que se tem por certo, não ser atingida ou que tenha sua consolidação em um longo tempo, que as vidas humanas não comportam - sintomas esses de uma exponencial atomização da população - é inerente ao regime totalitário para sua manutenção, pois a partir do presente sombrio e da promessa de um futuro melhor, a violência no primeiro momento, e o terror são aceitáveis e legitimados. Por estar trabalhando apenas com movimentos de extrema-direita cito duas passagens, referentes respectivamente a nazismo e ao integralismo:

Himmler, que conhecia também a mentalidade daqueles a quem organizava, descreveu não apenas os membros da $\mathrm{SS}$, mas as vastas camadas de onde os recrutava, quando disse que eles não estavam interessados nos 'problemas do dia-a-dia’, mas somente em questões ideológicas que 'trabalham numa grande tarefa que só aparece uma vez a cada 2 mil anos.' (Arendt, 1989: pp. 365-366)

Plínio Salgado é mais modesto em seus prazos de longa duração, quando diz que "Nossa campanha durará, pelo menos um século. Os camisasverdes realizarão paradas e desfiles, conferências, cursos, estudos, não com a mentalidade dos galináceos, que não consideram nada além do exíguo terreiro, mas com a visão das grandes aves de asas abertas no infinito azul.'(Salgado, 1955b: pp. 256-257)

A adesão em massa a este tipo de discurso demonstra a necessidade do indivíduo em pertencer a um grupo, acima da importância em perceber 
ou vivenciar o resultado final de sua ação. Há a sobreposição da massificação sobre o instinto de autoconservação por parte dos indivíduos massificados. Todavia, ainda que diante da abrangência dentro do mesmo conceito, os movimentos possuem diferenças ora extrínsecas ora inerentes a si. Moore aponta alguns tipos-ideais para explicar os mecanismos de eclosão para as lutas pelo poder, dentre estes estão:

O primeiro caso, o mais simples, é aquele em que a sociedade empreende uma nova série de atividades que, pela própria natureza, requerem elevado grau de coordenação central. O segundo, muito mais complexo, ocorre quando um choque externo ou uma decadência interna produz um movimento no sentido da compulsória reintegração da sociedade, em padrões novos ou parcialmente novos de comportamento. (Moore, 1972: p. 12)

Não há dúvidas que Brasil e Europa viviam momentos distintos em seus respectivos percursos. Neste modelo, o primeiro caso poderia ser aplicado ao contexto brasileiro, quando se inicia a implantação da produção industrial no país, predominantemente agrário exportador até então; enquanto a Alemanha principalmente, mas também a Itália e todo o restante da Europa amargavam um período de depressão por terem sido palco da I Guerra Mundial, sofrendo colapsos econômicos e políticos, sincrônicos à tarefa de reconstrução. Desta forma, mesmo sabendo que estes modelos propostos são tipos ideais, que podem ser utilizados nas mais diferentes conjunturas ao longo da História, estes momentos díspares podem ser encontrados nas falas e queixas das lideranças do Sigma e do Nazismo.

O Esperado é um romance que evidencia a perspectiva negativa de Salgado a respeito do contexto da "Revolução de 1930", fase da história do Brasil onde o processo de industrialização se acentua, influindo diretamente na organização política e sociocultural do país. Embebidos em sua ideologia anti-burguesa liberal e anti-cosmopolita, anticomunista, e nacionalista onde ironicamente -, o autor escreve no prefácio da primeira edição que: "Êste 
romance não defende nenhuma tese" Salgado (1955b: p. 23) expõe uma situação e procura marcar tipos expressivos de uma sociedade angustiada.

Para citar amostras das sensações que o autor transparece sobre as mudanças daquilo que chama de "estado de espírito do país", logo no prefácio da terceira edição de $O$ Esperado, Salgado apresenta que "Desde a revolução política de 30, criou-se um estado de espírito novo no Brasil. Daí o súbito aparecimento de inúmeros 'romances sociais"'(Salgado, 1955b: p. 18). Completando com a contraposição do Brasil urbano e acelerado das décadas de 20 do século passado, com o agrarismo encontrado no interior do país convivendo sincronicamente:

Carrilhões azuis! E as fábricas que mugem - tornos zumbindo, limas-cigarras cantando nos ossos de aço, fornalhas, teares troantes; e, longe, os tratores arranhando, em todos os sentidos, a terra; arados mordendo o peito do sertão; cantigas matrimônios, germinações fervendo, vozear irrevelado de vozes... (Salgado, 1955b: p. 41).

O que importa para o momento é a observação das dissonâncias vividas entre Brasil e Europa no referido contexto. Ambos os recortes geográficos passam por crises entre as décadas de 1920 e 1930, contudo em situações distintas. Enquanto contexto político-econômico brasileiro era de transição de uma elite agrária em declínio, para um desenvolvimento inicial do âmbito industrial, com presente investimento das "novas elites" cafeeiras, e seu escoamento industrial da lavoura para a fábrica, a Alemanha e a Itália, assistiam com temor a intensificação do desenvolvimento da cultura política operária, que se acentuava no período entre-guerras.

Gramsci (1974), em sua obra El 'Risorgimento', relata a tensão que circunda a unidade nacional italiana e, mesmo após o processo, a turbulência política que eclodiu com maior intensidade entre os anos de 1919 e 1926 período que compreendia o recorte que ficou conhecido os "Anos de Grande Medo", cenário acentuado ainda pela tendência ao separatismo do Norte (industrializado) em relação à região conhecida com Mesoggiorno (parte agrária 
da península itálica). Opiniões de que o Sul (camponês) era a bola de chumbo para o desenvolvimento econômico do restante da Itália se disseminavam por todo o território ${ }^{3}$. Acentuando a crise interna, há a organização inicial neste período, de camponeses e operariado na realização de paralisações e greves, o que desestabiliza os setores aristocráticos mais fragilizados no período pós-formação do Estado nacional:

(...) en 1920 los latifundistas sicilianos se reunieran em Parlermo y pronunciaran um verdadero ultimátum contra el gobierno "de Roma” amenazando con la separación, (...) muchos de estos latifundistas continuaran manteniendo la ciudadania española e hicieran intervenir diplomáticamente al gobierno de Madrid (caso del Duque de Bivona em 1919) para que protegiera sus intereses amenazados por la agitación de los campesinos ex-combatientes. (Gramsci, 1974: pp. 106-107)

Este cenário de separatismo, junto a maior organização do operariado fabril e dos camponeses, fomentando um período endêmico de greves instalado na Itália ao iniciar do século XX, causam a instabilidade política e economia no país. Nesta conjuntura que divide espaço com a ambição imperialista e desenvolvimento do capital industrial dentro da península itálica, torna-se tentadora a possibilidade da burguesia juntar forças com os setores conservadores temerosos com os levantes do proletariado no intuito de retomar o equilíbrio na ordem dominante anterior. Estes ingredientes são catalisadores da ascensão de Mussolini e suas ideias nacionalistas calcadas no Império Italiano e na romanidade, que reduzem o potencial separatista, e ambições expansionistas a partir da concepção do Mare Nostrum. (Konder, 1977: p. 21)

\footnotetext{
3 “En tanto quedó la em el Norte creencia de que el Sur era una 'bola de plomo', para la Italia, la persuasión de que la civilización industrial moderna de Alta Italia hubiera hechos progresos mucho más grandes sin esta 'bolo de pomo', etc. A principios del siglo se inicia uma fuerte reacción meridional, también em esto terreno..." GRAMSCI, Antonio. El "Risorgimento". Buenos Aires: Granica, 1974. pp. 108-109.
}

Temáticas, Campinas, 20(39): 145-180, jan./jul. 2012 
$\mathrm{Na}$ Alemanha, Barrington Moore expõe que a debilidade e temor da burguesia, convergiram para a constituição da aliança para com a aristocracia na tarefa de modernização industrial, o que evidentemente suscitaria a modificação estrutural política, econômica e social, principalmente no cotidiano dos setores inferiores da sociedade alemã $\tilde{a}^{4}$ Tal conjuntura contribui para a radicalização das divergências entre proletariado e camadas superiores da sociedade, destaque para os setores da aristocracia conservadora e da promissora burguesia industrial alemã.

Temendo pela reação dos setores populares, operariado e camponeses, há a implementação de uma política excludente dos mesmos, beneficiando buscando silenciar - os revoltosos em potencial com políticas sociais tais como ampliação e desenvolvimento dos direitos trabalhistas. Tal política fora iniciada ainda no governo de Bismarck, com o surgimento do proletariado, absorvido a partir do lúmpen campesino existente anteriormente, expropriado pela concentração fundiária, e formado a partir do êxodo nos campos.

Delgado afirma que a origem das políticas sociais de Bismarck surgiu "dentro de uma configuração de mercado que exibia expressivas concentrações operárias, as políticas sociais apareceram como resposta da coalizão do ferro com o centeio ao dinamismo do movimento operário socialdemocrata" (Delgado, 2006: p. 10). O que implica numa organização e mobilização operária precedente à iniciativa do Estado, pressionando por melhorias nas condições de trabalho, diante da penetração do mercado na vida dos alemães de forma universal e hegemônica, tornando-os “mercadorizados". Neste aspecto há o diálogo aberto com Pimenta de Faria quando este disserta que no momento da construção das políticas sociais no Alemanha de 1880, dois aspectos saltam aos olhos: "seu caráter seletivo ou corporativo e seu propósito explícito de pacificar os operários industriais, minar organização trabalhista e promover a paz social." (Faria, 1998: p. 50)

\footnotetext{
4 "A situação durante a primeira metade do século XIX. E mesmo consideravelmente mais tarde, contrasta muito acentuadamente com a que existiu na Alemanha, onde nessa altura (e mais tarde também) uma burguesia mais fraca se apoiava na aristocracia proprietária de terras proprietária de terras para se proteger do descontentamento popular e levas a cabo medidas políticas e econômicas necessárias à modernização" (MOORE, 1983, p. 41).
} 
Em consonância com essa ideia, o Welfare-State alemão, segundo Marshall, foi posto em prática para fragmentar a solidariedade operária ao fazer a distinção entre o sistema de seguridade social e ação assistencial geridos pelo Estado, pois, "No primeiro, quanto mais se tivesse, tanto mais se receberia (e também contribuiria), mas nesta última, na qual se empregava um teste dos meios, quantos mais se tivesse, tanto menos se receberia."(Marshall, 1967: p. 65) de modo que aqueles que sofressem acidentes de trabalho e fossem incapacitados de exercer suas funções no meio fabril, sofreriam o estigma de ser um ente parasitário da contribuição dos demais trabalhadores e do Estado.

Esta conjuntura de projeção industrial, seguida da organização do operariado, é acentuada nas primeiras décadas do século XX, com a derrota na I Guerra Mundial e as penalizações infligidas pelo Tratado de Versalhes, contribuindo para o cenário de desequilíbrio social e incertezas políticas. Como reflexo destas circunstâncias é ilustrativo e conhecido o amplo apoio financeiro fornecido a Hitler, por industriais e banqueiros alemães, para a manutenção do partido Nazista quando este passava por dificuldades financeiras em diversos momentos de sua existência, com as contribuições se acentuando no pós-1929.

Os fatores presentes na Itália e na Alemanha, a partir de Gramsci e Moore, caminham para o processo que Moore, em Origens Sociais da Ditadura eda Democracia, chama de modernização conservadora ou Revolução vinda decima. $\mathrm{O}$ autor utiliza o conceito de modernização conservadora para descrever a conjuntura interna do Japão, da Itália e da Alemanha, países que tiveram o fascismo como alternativa política vitoriosa como opção de ascender ao poder, no momento de crise. Nesses termos, Barrington Moore aborda que:

No Japão, a noção de compromisso total perante a autoridade proveio, aparentemente, mais do aspecto feudal da equação do que de seu aspecto monárquico. Também na Itália, onde o fascismo foi inventado, não havia uma monarquia nacional poderosa. Mussolini teve de chegar à antiga Roma para conseguir encontrar o simbolismo correspondente. Numa fase posterior do discurso da

Temáticas, Campinas, 20(39): 145-180, jan./jul. 2012 
modernização, é provável que apareça um fator novo e crucial, sob a forma de uma coligação grosseira entre os setores influentes das classes fundiárias e os interesses comerciais e industriais emergentes. (...). Marx e Engels, na sua dissertação sobre a revolução abortada de 1848 na Alemanha, embora errados em outros aspectos, puseram o dedo neste ingrediente decisivo: uma classe comercial e industrial demasiada fraca edependentepara tomaropoder egovernarporsen direito próprio, e que, por isso, se lança nos braços da aristocracia proprietária e da burocracia real, trocando o direito de governar pelo direito de ganhar dinheiro. É necessário acrescentar que, mesmo que o elemento comercial e industrial seja fraco, deve ser suficientemente forte (ou em breve tornar-se suficientemente forte) para constituir um aliado político digno de valor. Caso contrário, pode surgir uma revolução camponesa que leve ao comunismo (Moore, 1983: p. 433).

Ao deixar de lado as conjunturas para explorar os movimentos em seu interior, existem ainda iguais diferenças que por mais sutis que possam ser, fazem-se necessárias de serem consideradas. São estas dissidências, além de vetores intrínsecos aos movimentos, que são divergentes e inconciliáveis entre fascismo e integralismo, que serão abordados no item a seguir.

\section{OS FASCISMOS E O INTEGRALISMO: O QUE UNE E O QUE DIFERENCIA}

A relação e o contato entre as duas ideologias e os movimentos em questão, com ênfase na influência do regime de Mussolini para com a AIB, é marcado por avanços e retrocessos no que tange à assimilação do primeiro pela segunda. Estes movimentos ora de aproximação ora de negação entre o integralismo e os fascismos, são estratégias adotadas pela Ação Integralista, nem sempre racionalmente, ditada dentre outros determinantes, pelo contexto 
histórico e associada, em parte, aos humores da opinião pública brasileira a respeito dos governos de extrema-direita da Europa. Este aspecto não significa total maleabilidade da AIB em relação aos fascismos. Aquela tinha autonomia em relação ao segundo devido às outras mananciais teóricas, conforme terei a oportunidade de demonstrar a seguir.

Diante dessas contribuições, é necessário expor, ainda que de maneira esquemática, um esforço de caracterização a respeito das condições que, segundo um autor estadunidense (Paxton, 2007), serviram de bases de sustentação para os fascismos de modo geral. Os itens enunciados pelo autor, tanto quanto sua obra recente, bastante comentada em determinados círculos acadêmicos, prima pela simplicidade em sua exposição, aspecto que algumas vezes pode surgir como desvantagem para a argumentação de sua tese. Portanto, segue em tópicos o que o autor entende pelas razões mobilizadoras do fascismo ${ }^{5}$ :

- um senso de crise catastrófica, além do alcance de soluções tradicionais;

- a primazia do grupo, perante o qual todos têm deveres superiores a qualquer direito, sejam eles individuais ou universais, e a subordinação do indivíduo a esses deveres;

- a crença que o próprio grupo é vítima, sentimento esse que justifica qualquer ação, sem limites jurídicos ou morais, contra seus inimigos, tanto internos quanto externos;

- o pavor da decadência do grupo sob influência corrosiva do liberalismo individualista, dos conflitos de classe e das influências estrangeiras;

\footnotetext{
${ }^{5}$ Por não ter acesso à obra em inglês, desejo crer que a citada pesquisa apresenta alguns problemas suscitados talvez na passagem do texto de sua língua vernácula para o português, visto que não cabe a um professor de História Contemporânea do Columbia University dizer que "Mussolini, da mesmo forma que Hitler, utilizou de campos de concentração e de limpeza étnica e usou gazes tóxicos, coisa que Hitler nunca ousou fazer." (Grifo meu). PAXTON, Robert. op.cit. p. 42. Não sendo este o melhor lugar para o enfoque crítico da obra, abordo apenas os pontos que são positivos.
}

Temáticas, Campinas, 20(39): 145-180, jan./jul. 2012 
- a necessidade de uma integração mais estreita no interior de uma comunidade mais pura, por consentimento se possível, pela violência excludente, se necessário;

- a necessidade de chefes naturais (sempre do sexo masculino), culminando num comando nacional, o único capaz o destino do grupo;

- a superioridade dos instintos do líder sobre a razão abstrata e universal;

- a beleza da violência e a eficácia da vontade, sempre que voltadas para o êxito do grupo;

- o direito do povo eleito de dominar os demais, sem restrições provenientes de qualquer tipo de lei humana ou divina, o direito sendo decidido por meio de critério único das proezas do grupo no interior da luta darwiniana. (Paxton, 2007: p. 360).

Poucas palavras são destinadas quanto ao integralismo na obra de Paxton. Sobre o assunto é feita apenas uma breve referência classificando-o como "a coisa mais próxima a um partido de massas fascista nativo da América Latina" (Paxton, 2007: p. 314). Conforme fora mencionado acima, a fórmula acessível e bastante simples de trabalhar os conceitos e apresentar os fatos, fornecem alguns embaraços para o autor no momento de sua exposição.

Exemplo do prejuízo teórico suscitado pela síntese de ideias é encontrado ao se cruzar o modelo típico-ideal dos motivos que fomentam movimentos fascistas, em confronto com a realidade de emergência da Ação Integralista Brasileira. A noção de pureza racial não consta nos pensamentos de Salgado em nenhum momento de suas obras, devido à intervenção do cristianismo em sua teoria. Em livro destinado ao público infantil, Plínio expõe que:

(...) um gosta mais de café, outro de chocolate, outro de doce de côco, outro de pudim; (...). Mas tudo isso, que são diferenças necessárias para a distinguir a personalidade de cada um de vocês não altera as coisas que são iguaizinhos: 
todos falam a mesma língua, todos acreditam em Deus, todos querem bem seus pais, todos se estimam mutuamente, todos são educados segundo o mesmo princípio de moral, todos se orgulham de ser brasileiros. (Salgado, 1954: pp. 277-278)

Nestas palavras há a síntese de suas teses nacionalistas de forma clara e direta. Ao descrever os aspectos de igualdade que unem as crianças as quais ele escreve, Plínio insere na mesma afirmação a unidade linguística, que remete indiretamente à identidade nacional. Está última reforçada posteriormente pelo orgulho de ser brasileiro, colocado ao final da citação. Em seguida acrescenta a crença em Deus, que conforme já foi dito, é característica importante na teoria do chefe da AIB, tanto por promover a unidade e relativizar as diferenças étnicas que se apresentam no âmago da população brasileira, em prol da unidade da "Raça Harmoniosa", quanto para incitar uma nova cruzada interna e externa contra os infiéis (todos aqueles que representassem empecilho para o sucesso dos projetos políticos AIB, sejam os obstáculos o comunismo, seja o "imperialismo cosmopolita"). Adiante inclui "todos querem bem seus pais", encerrando desta forma os pilares do integralismo de Plínio Salgado, fixados no tripé "Deus, Pátria e Família”.

Em outra de suas obras, quando Salgado disserta sobre o destino do Brasil, é presente a noção do país como recipiente da pluralidade étnica e religiosa, da dissolução da luta de classes. Os argumentos são apresentados nos seguintes termos:

Que missão estará reservada a esta grande Pátria? Que contribuição trará ela à Humanidade do Futuro? Tudo nos indica que desafogarão em nós, e aqui desaparecerão, todos os ódios de raças ou de religiões, de classes ou de nacionalidades, e um tipo de humanidade melhor poderá surgir na terra Jovem. (Salgado, 1957: p. 125)

Desta forma, o último tópico formulado por Paxton fica igualmente comprometido quanto a inserção do integralismo à fronteira de movimento 
fascista. Pode se chegar a esta conclusão visto que para o chefe da AIB não há um povo eleito, pois a raça superior seria constituída a partir da fusão de todos os povos, conforme acreditava Plínio. Desta maneira se consolidaria a chamada Raça Cósmica, da forma enunciada pelo escritor e Ministro da Educação Pública do México José Vasconcelos (1986) e reproduzida por Salgado.

Outro vetor de constrangimento teórico é causado pelo fato de Paxton entender como aspecto específico ao Fascismo, a necessidade de chefes naturais que canalizem o destino do movimento em sua pessoa. No regime soviético, por exemplo, há a figura do líder, como ícone representativo de todos os anseios do partido, contudo, não é lícito afirmar que os fascismos e o socialismo soviético são similares. Dizer isso seria o mesmo que ignorar características particulares e essenciais a cada uma das duas formas de totalitarismo, que entre outras demais são: a origem de classe e a natureza de cada movimento, bem como a diferenças entre os objetivos e as ideologias tanto do socialismo da URSS como dos regimes fascistas.

Conforme demonstrado, não é pertinente com suficiência, tecer fórmulas para que se possa classificar um movimento como inserido ou não na lógica fascista sem antes observar os problemas internos que condicionaram seu surgimento, além de captar os meandros ideológicos que compuseram seu arcabouço teórico como forma de resposta e reação às questões que provocaram sua emergência. Mesmo diante da nítida contribuição teórica e simbólica fornecida pelos fascismos ao integralismo, é necessário fazer algumas pontuações quanto à origem destes afluentes teóricos.

Embora Paxton tenha méritos pela acessibilidade à leitura e simplicidade na descrição teórica, o que permite atingir o grande público de leitores, a obra que disserta com maior profundidade sobre a teoria fascista em sua essência e composição, fazendo a reflexão dos componentes do fascismo é a do autor Edvard Benes (1945).

Transcendendo a análise do livro e de suas ideias, os relatos de Edvard Benes possuem maior valor histórico pois o autor, na data de edição da obra, ocupava a presidência da Tchecoslováquia, país invadido pela Alemanha nazista durante o mandato de Benes, sob o respaldo da "questão de Sudetos" região povoada por grande número de alemães, estando então abrangida 
pelo pan-germanismo propagado pelo III Reich, como prerrogativa da incursão militar. Ao examinar a origem e a formação do Fascismo, Benes parte da explicação de que este teria como orientador teórico a máxima que

(...) a individualidade humana é determinada, caracterizada e condicionada por apenas aquelas suas qualidades que correspondam ao dinamismo, o relativismo, o biologismo animal e o vitalismo, e podem mais facilmente conciliar com o materialismo metafísico: a vontade o instinto e a emoção. O voluntarismo, o empirismo e o intuitismo nas suas extremas formas material-positivistas constituem as presunções para julgar a tarefa objetivo e a atividade do indivíduo e da nação. (Benes, 1945: p. 124)

Benes afirma que o Fascismo italiano insurge especificamente contra a ordem vigente, se opondo à imperfeita máquina democrática vigente naquele país. A princípio, frente a sua carência de embasamento filosófico, "Era apenas uma coleção de ideias vagas e dispersas, de proclamações e reações sensacionais.” (Benes, 1945: p. 125). Desta forma, temos por início a definição das características que envolviam a teoria do regime de Mussolini.

Conforme se pode observar, há no fascismo italiano pontos de contato em suas raízes teóricas com o integralismo, tal como a derivação do materialismo-positivista, por mais que haja a refuta de Plínio Salgado. Entretanto, mesmo possuindo o berço teórico semelhante, a maneira como que esta influência foi absorvida se faz distinta, podendo se arriscar dizer que a presença do positivismo, conforme é apropriado por ambas as ideologias nos pontos captados, torna-as divergente em alguns aspectos importantes.

Em lugar do empirismo do qual o fascismo italiano é revestido, ao termo de Mussolini subir ao poder sem uma carta programa de governo sólida, no integralismo assiste-se o oposto: o excesso de regras. A forma prolixa que se dão as doutrinas e a organização dos eventos e cerimônias (O Monitor Integralista. Primeira Quinzena de maio de 1934) são fatores recorrentes nos protocolos da AIB. Portanto, mesmo na semelhança de seus 
afluentes teóricos, é necessário sondar como entes influem na organização e atuação de cada qual dos autoritarismos abordados.

Sobre o fascismo alemão, Benes expõe que:

De acordo com a filosofia nazista, a História da humanidade constitui simplesmente uma luta da raça superior com as raças inferiores e o sentido da História deveria consistir no esforço da vitória da raça superior, que depois guiaria a Humanidade. Esta opinião rejeita tenazmente e por princípio a afirmação da igualdade de tôdas as raças e tôdas as nações, asseverando, ao contrário, a sua desigualdade. (Benes, 1945: p. 139)

O racismo defendido pelo nazismo, ressaltando a superioridade eugênica do povo teuto-ariano, torna inconciliável à igualdade pregada pelo catolicismo enaltecido pelo chefe do integralismo. Salgado insistia em ressaltar o caráter agnóstico do nacional-socialismo como forma de repúdio a este, o que na opinião do líder do integralismo não se repetia com fascismo italiano. Aspecto que, considerando a influência católica que beira ao fanatismo qual Salgado é dotado, possui lugar importante, mesmo considerando as relações pouco amistosas entre Mussolini e a Igreja Católica, ainda assim, melhor que o comportamento de Hitler para com as religiões, na concepção do chefe da Ação Integralista.

Como depoimento do agnosticismo criticado por Salgado, tem-se o registro de Albert Speer onde o Ministro dos Armamentos do Reich nazista, nos lances finais da II Guerra Mundial, descreve a autoconfiança de Hitler apoiada em algo inexplicável e metafísico, porém, não correspondente ao Deus católico do chefe da AIB. Segundo Speer, Hitler fundava sua crença no

\footnotetext{
6 "De certo modo, êle [Hitler] adorava a si próprio. Em qualquer momento tinha diante de si um espelho no qual via não somente sua imagem refletida como também a confirmação da missão que lhe fôra confiada pela Divina Providência. Sia religião era o "grande Acaso", que haveria de beneficiá-lo; seu método de autofortalecimento por sugestão.” SPEER, Albert op. cit. p. 98.
} 
"grande Acaso" "que o levaria à missão que acreditava lhe ter sido enviada como objetivo: a vitória da raça superior.

Expandindo o foco da crítica, conforme pude demonstrar a partir das ilustrações 1 e 2, Salgado é taxativo e fornece duros ataques ao regime nazista quanto ao comportamento do mesmo dispensado aos católicos que lá estavam assentados, como pode ser percebido logo na introdução onde o chefe da AIB escreve:

O último telegrama da Alemanha informa que o governo de Hitler mandou prender cerca de 150 sacerdotes católicos e centenas de membros de associações católicas, acusados de conspirar contra a segurança do Estado.(...) Que atos teriam praticado os católicos germânicos para incorrer na cólera do Estado Hitlerista? (Arquivo Público e Histórico de Rio Claro-SP - Fundo Plínio Salgado: cx. 003.007.002)

Outros fatores pesam contra Hitler sob a perspectiva de Salgado, tais como o racismo e a supressão das massas, que segundo Plínio, era ação particular ao nacional-socialismo e ao socialismo soviético ${ }^{7}$, poupando o fascismo italiano de maiores críticas. Em Mein Kampf-registro de experiências escrito em 1924 quando Hitler estava em um presídio militar, resultado do frustrado putsch de Munique - o líder nazista expõe suas impressões e visão de mundo sobre o contexto que vivenciava. Neste diário é apresentada como algumas das razões principais da derrota alemã na I Guerra Mundial a infiltração judia no estrato burocrático governamental do Reich alemão, primeiro estandarte do nacionalismo nazista, vinculado ao antissemitismo. $\mathrm{Na}$ justificativa do insucesso em 1918, Hitler expõe que:

\footnotetext{
7 “Oriundo das massas, e não do povo organizado segundo as hierarquias raciocinantes, trouxe, como vício de origem, o capricho despótico das multidões tornadas agora passivo instrumento. Em luta tão desigual, o Homem sucumbia, ficou somente a coletividade dos dois totalitarismos em voga: o nacional-socialista e o internacional socialista" (SALGADO, Plínio. Primeiro, Cristo! op. cit. p. 135).
}

Temáticas, Campinas, 20(39): 145-180, jan./jul. 2012 
Infelizmente a dominação do dinheiro foi sancionada justamente onde deveria ter encontrado mais oposição. Foi uma infeliz inspiração a de sua majestade induzir a nobreza a entrar no círculo dos novos financistas. Sirva de desculpa para o Kaiser o fato do próprio Bismarck não ter compreendido esse perigo. (...)

Não era nada convidativo aos verdadeiros heróis e aos estadistas serem colocados no mesmo plano dos judeus dos bancos. (...)

Sob o ponto de vista racial, esse fato era de consequências deploráveis. A nobreza perdia cada vez mais a razão racial de sua existência e, na sua grande maioria, podia-se com propriedade dar-lhe o qualificativo contrário (Hitler, 2001: p. 176).

Salgado, por sua vez, refuta o antissemitismo em sua teoria, embasado, conforme já fora dito, em sua forma evangelizadora/imperialista de apresentar o cristianismo, uma das principais composições de sua teoria de "Raça Harmoniosa" que constituiria a fusão de todas as raças, tendo no caboclo o elemento principal de coesão inter-racial. Porém, vale adiantar que enquanto Salgado demonstra tolerância à mestiçagem, o mesmo não acontece ao que toca a aceitação religiosa.

Da forma como é aplicada na teoria de Plínio, a fé católica torna-se arma de expansão imperialista, avançando e incorporando os povos não cristianizados Outro marco de diferenciação entre a AIB e os fascismos europeus, segundo afirma o chefe integralista - fonte que sempre deve ser posta sobre o mais cuidadoso olhar crítico, estaria estacionado sobre o anti-messianismo propagado por Plínio Salgado. O chefe dos camisas-verdes apresenta que:

É justamente porque o nosso movimento difere do italiano e do alemão que devemos libertar-nos, definitivamente da adoração dos homens, que é ainda remanescente de uma época morta. A Humanidade Nova abandonará os últimos 
prejuízos das idolatrias. A idolatria da Massa, na Rússia, como a idolatria do Homem, na Alemanha ou na Itália, como a idolatria do voto, nas liberais-democracias, são todos resíduos de um século morto. (Salgado, 1955c: p. 257)

Na esteira oposta, há o contato do integralismo, segundo Plínio Salgado, com o “(...) fascismo italiano, ao qual somente nos assemelhamos no concernente à nova atitude do Estado, em face da luta social”' (Salgado, 1957: p. 83). Conforme vem se demonstrando, não era apenas essa a semelhança entre o movimento de massas brasileiro e o regime de massas italiano, tampouco era destinada participação diminuta do nazismo conforme o narrado por Plínio Salgado, na teoria do Sigma.

Para esclarecer tais questões, reservo-me à análise de aspectos importantes que se confrontam - tanto para as semelhanças, quanto para as especificidades - entre o nazismo, o fascismo italiano e o integralismo neste âmbito. A seguir, far-se-á a abordagem de como ambos os regimes (fascismos e integralismo) se comportavam e qual a função da religião, do racismo e da propaganda, para a manutenção da coesão e da ordem interna e da busca pelo poder.

Como foi visto, a religião é bastante cara para apontar as diferenças entre integralismo e fascismo, pois é neste campo que se sustentam, por exemplo, parcela importante das estruturas do totalitarismo integralista de Plínio Salgado - ao contrário dos fascismos, que defendem a preservação da raça e a manutenção do corporativismo como vetor do totalitarismo -, mas não somente isto. É no catolicismo que Salgado encontra justificativa para sua teoria de Raça Harmoniosa e o antirracismo, além de encontrar nos ditames divinos os rumos da Revolução qual o líder da AIB propaga como sendo a ideal. Porém, curiosamente, o chefe da AIB enreda o integralismo como teoria anti-messiânica. Estes pontos serão desenvolvidos um por um nesta parte da pesquisa.

Adorno expõe que "O antissemitismo racista quer se abstrair da religião. Ele afirma que se trata da pureza da raça e da nação. Os nacional-socialistas notaram que os homens há muito deixaram de se preocupar com a salvação eterna" (Adorno \& Horkheimer, 1985: p. 164). Salgado, ao contrário, afirmava 
a presença da religião em meio a AIB como quesito de estruturação moral, atuando de forma direta em sua ideologia e visão de mundo.

São recorrentes nos textos do chefe do integralismo as associações do comunismo para com satanismo, e que o destino teleológico do integralismo perpassaria por uma nova cruzada contra o "mal"». Nesta tarefa, Plínio imputa ao comunismo e ao materialismo burguês todas as degenerescências morais, com o fim de tornar, através de uma significação direta, o comunismo um sintoma do estilo de vida burguês cosmopolita. Este instrumento de retórica, de anexação do comunismo ao liberalismo, recriminando ambos como formas imorais ou amorais de se viver, é ligado diretamente ao discurso católico que

(...) considerava sagrado o direito à propriedade, natural a desigualdade entre os homens e erradas as tentativas de questionar a ordem social, posições certamente que os liberais consideravam muito simpáticas (e úteis). Mas, ao mesmo tempo as fontes eclesiásticas demonstravam desagrado para com certas características da sociedade capitalista, como o estímulo ao materialismo, o enfraquecimento da moralidade tradicional e a excessiva exploração dos trabalhadores. (Motta, 2002: p. 45)

Observando o trecho: "Satanás é o comunista que assassina à traição. Satanás é o homem rico e feliz, que assiste esse crime e sorri” (Salgado, 1955c: p. 244), há um desequilíbrio entre riqueza simbólica e pobreza de significantes. É presente a relação de cumplicidade entre o comunismo e o "homem rico", ligados pelo vínculo de ambos encarnarem a figura de Satanás, e os dois ocuparem o papel de traidores, pois enquanto um assassina, o outro assiste

\footnotetext{
8 "Vivendo numa época semelhante à da invasão maometana contra o ocidente repetimos, como no tempo das cruzadas, o episódio maravilhoso da união e do bom combate em que se empenham todos os que se esforçam para salvar os valores legítimos da civilização cristã, aperfeiçoando-a ainda mais.” SALGADO, Plínio. Páginas de Ontem. In. Obras Completas. v. 10. São Paulo: Editôra das Américas, 1955d p. 196.
} 
com complacência. Entretanto, não há qualquer explicação a respeito deste vínculo entre Satanás, o burguês e o comunista, apenas a constatação.

Esta fraseologia representa poderoso formador de concepções e identidade, levando ao receptor integrante da massa, à sensação de estar sendo informado, devido à riqueza de símbolos expostos no discurso, convertendo mensagem em opinião. Para Paul Ricoeur, na ideologia, "sua capacidade de transformação só é preservada com a condição de que as idéias que veicula, tornem-se opiniões, de que o pensamento perca o rigor para aumentar sua eficácia (...).” (Ricoeur, 1983: p. 69)

Trata-se então da desmobilização do sistema de pensamento, transmutando-o para o sistema de crença. Para a existência da simpatia, adesão e participação em um movimento totalitário, antes é necessário que as mensagens sejam portadoras de uma falsa completude de seu conteúdo e significado, constituindo desta forma os escalões daqueles que detêm a maior parte da verdade, de maneira hierárquica, até se atingir o Chefe, aquele que ditará os rumos do grupo e portador da verdade e do destino do povo.

Neste ímpeto, a traição cometida pelo comunista e pelo burguês, contida na frase do líder integralista, pode se referir tanto à infração contra o indivíduo ou à família quanto pode ser levada para um nível mais amplo, à traição da nação, pois segundo Salgado:

Muita gente há que se diz socialista e acreditar em Deus. É porque não estudou o socialismo. O socialismo baseia-se no materialismo. Outros há que apóiam o comunismo, o esquerdismo de todos os matizes, dizendo-se respeitadores da família, absurdo que depõe contra a inteligência de quem o adota, pois o comunismo quer destruir. Outros há que falam em Pátria, sendo partidários dos bolchevistas. Todos esses não passam de "fôrças de vanguarda", dos quais Lenine desdenha e se aproveita (Salgado, 1955c: p. 218).

Sob esta lógica retilínea é que se consolida o slogan integralista de "Deus, Pátria e Família”. Contra estes três pilares se ergue o inimigo a ser combatido, que é o Capitalismo cosmopolita e o Comunismo. Segundo Salgado 
(1955c: p. 229) "são dois nomes para designar a mesma coisa: o materialismo." Capta-se no tripé integralista a relação estreita com a moral, vinculo estabelecido também pelos fascismos.

Todavia, a moral é utilizada de forma retórica pelos "camisas-verdes", usando-a para legitimar as ações da AIB e de seus integrantes. No caso do fascismo italiano ${ }^{9}$ e do nazismo ${ }^{10}$, estes enraízam todo seu código jurídico no respaldo do princípio ético abstrato, o que a torna o critério legal, subjetivo e impalpável visto que é fundado sob as concepções morais particulares do legislador, não possuindo o caráter objetivo e amplo qual seria o esperado para um código de leis.

Esta flexibilidade calcada na abstração, feita sobre o subsídio do termo moral, é resultado da conhecida ausência de programa qual eram imbuídas as plataformas de governo de Hitler e Mussolini. Contudo, a AIB era revestida por um aparato regimental, ainda que bastante elementar (O Monitor Integralista. Segunda quinzena de dezembro de 1933. Arquivo Público e Histórico de Rio Claro-SP- Fundo Plínio Salgado: cx 131.021-131.038) antes de atingir grande amplitude, porém, com o maior crescimento do movimento em proporção nacional, atinge a complexidade de sua organização e funcionamento (Ver Ilustrações 2 e 3).

Referências a "Deus, Pátria e Família" são de baixa constatação tanto

\footnotetext{
9 “'O 'Direito objetivo' significa a lei criada pelo soberano ou, de qualquer forma, a lei atributível ao poder soberano; direitos subjetivos significam as reivindicações da pessoa jurídica do indivíduo. Um nega a autonomia do indivíduo, o outro a pressupõe e afirma. Várias são as teorias que tem procurado conciliar a contradição expressa por êsses dois têrmos. Algumas vêzes os direitos subjetivos são tidos como simples reflexos do Direito Objetivo - uma proposição que nega completamente a autonomia do indivíduo. (Essa teoria alemã que se desenvolveu e floresceu no século XIX foi adotada pelo fascismo italiano.)” (Neumann, 1969, p. 32).

10 "Proposições como as seguintes: contratos que violarem normas públicas, ou sejam imorais e não tenham razão de ser (Parágrafo 138 do Código Civil Alemão, BGB) são nulos e inválidos; ou aquêle que cause danos a alguém de forma que seja uma violação da boa moral fica responsável pelas indenizações ( Parágrafo 826); ou aquêle que tenha "cometer um ato que tenha sido declarado punível pela lei ou que merecer punições por ter entrado em conflitos com salutares sentimentos populares" deve ser punido ( Parágrafo 2 do Código Criminal do Reich Alemão, estipulado na Lei de 28 de junho de 1935), não são leis específicas com verdadeira generalidade." Idem, pp. 38-39.
} 
no hitlerismo quanto no fascismo italiano, exceto quando os líderes dos referidos regimes se colocam, eles próprios, no papel de messias ora para a preservação da integridade da raça ora para a salvação econômica, pela modernização via centralização totalitária. Ao contrário, o totalitarismo integralista se manifesta fortemente pelo viés da religião, sendo que "Se não cai uma folha sem que seja permissão de Deus, segue-se que tudo o que se verificou na História obedeceu a um pensamento superior. Lutamos contra o mal; mas às vezes êste triunfa. É o mistério, que a nossa compreensão limitada no tempo e no espaço não pode penetrar" (Salgado, 1955d: p. 13).

Sob este bastião, há a rejeição ao racismo pelo princípio cristão, bem como a assimilação do conceito de "Raça Cósmica", formulado pelo escritor mexicano José Vasconcelos, quando Salgado disserta a boa vontade em receber estrangeiros no seio da nação. O líder da AIB faz o convite:

Vem comigo, estrangeiro, a esta colina sagrada. Presta bem atenção nos grupos de romeiros que acorrem, constantemente aos pés de Nossa Senhora. São homens e mulheres morenos, louros, negros, caboclos, mulatos, africanos, europeus, asiáticos, trazendo das flores da fé e da esperança num preito de amor. É a confraternização de todas as Províncias Brasileiras, realizando a Unidade Nacional sôbre a base de um sentimento comum. É também a confraternização dos povos oriundos de todos os países da terra, que vieram a esta parte do Novo Mundo fundir-se, através das gerações para a formação definitiva de uma nação que desconhece os preconceitos da raça.

Vê: é uma Virgem Morena. A Sulamita do "Cântico dos Cânticos" quer significar, pela côr desta imagem, que $o$ verdadeiro cristianismo não pode conceber discriminações raciais.(Salgado, 1955e: p. 142-Grifo meu))

Este cenário exposto por Salgado é impensado na realidade fascista da Itália e da Alemanha. A primeira questão diferencial é a necessidade do integralismo de Plínio Salgado em se escorar ideologicamente no universo 
religioso. Isto afeta diretamente o caráter messiânico quais são revestidos os líderes fascistas, contudo rejeitado por Salgado ${ }^{11}$, o que por mais contraditório que pareça, não significa que Plínio Salgado exercesse mera figuração como chefe do Sigma. O movimento integralista é tomado de um aspecto orwelliano de totalitarismo, marcado pela onipresença do chefe supremo. ${ }^{12}$

Por mais que o chefe da AIB ignore o fato, era uma necessidade para Mussolini fazer sua ideologia de Estado se transformar em uma religião cívica. Ideia esta que inevitavelmente era incompatível com qualquer outro tipo de religião - entre elas a católica - que não fosse a pregada pelo Duce, ou seja, o Fascismo italiano. Outro motivo de rescisão com o Vaticano, é a proximidade geográfica da sede da Igreja, com a capital da Itália fascista, emanando discursos e intenções muitas vezes concorrentes as do Estado Novo italiano.

Logo, torna-se vital para a permanência hegemônica inquestionável qual necessitava a hierarquia corporativa de Mussolini, disputar fiéis com o Estado papal, para a consolidação da utopia fascista de dominação total dos corpos e mentes de seus seguidores. A secção entre Igreja e governo era algo crucial para a manutenção do sistema totalitário e reforço da ficção interna ${ }^{13}$.

$\mathrm{Na}$ Alemanha o desenrolar dos acontecimentos se manifesta de forma mais sutil, não havendo uma segmentação, e sim uma incorporação à política e ressignificação, não somente dos princípios cristãos como do folclore, de forma que as ações de violência e distúrbios sociais causados pela gestapo, pela juventude hitlerista ou qualquer outro agrupamento nazista, era legitimado através da tradição e enraizamento mítico-religioso germânico.

11 "Não estou chefiando este movimento por ambição pessoal. À proporção que ele cresce vou me sentindo desobrigado perante a História" (SALGADO, Plínio. Palavra Nova dos Tempos Novos. p. 292).

12 "Camisas Verdes! (...). Eu estou vos observando dia a dia, e sinto-me no dever de, uma vez por outra, levar minha mão aos refolhos de vossas almas, para galvanizar, lá bem no fundo, as energias sem as quais nada faremos de dignos de nossos descendentes." Idem, p. 314.

13 "Só a mimese se torna semelhante ao mundo ambiente, a falsa projeção torna o mundo ambiente semelhante a ela. Se o exterior se torna para a primeira o modelo ao qual o interior se ajusta, o estranho tornando-se familiar, a segunda transpõe o interior prestes a saltar para o exterior e caracteriza o mais familiar como algo hostil." ADORNO \& HORKHEIMER. op. cit. p. 174. 
Em outros lugares, observa Dumézil, a invocação das crenças dos antepassados se manteve artificial e retórica. $\mathrm{Na}$ Alemanha, pelo contrário, há 150 anos, as "belas lendas" dos germânicos foram não só popularizadas, mas também remisticizadas: elas se tornaram, em sentido estrito, mitos, já que justificam, provocam, sustentam comportamentos individuais e coletivos que tem todas as características de sagrado.(Ginzburg, 1989: p. 184-Grifo do original)

Porém, na teoria integralista esboçada por Plínio Salgado, algumas vezes nacionalismo e religiosidade encontram seus limites de interseção, observados, por exemplo, na função do imigrante no interior da nação. A referida "boa vontade" em receber o estrangeiro, defendida por Salgado, conforme acima esboçada, a partir de seus escritos, apresenta alguns ruídos e aspectos que merecem ser mais bem trabalhados. Se retornado ao trecho citado, de Geografia Sentimental, o líder da AIB não utiliza em momento algum os verbos aceitar, receber, acolher. Isto se repete enquanto temática da imigração no Brasil naquele contexto. Ao se referir ao comportamento para com os emigrados, do utópico Estado Integral, os termos utilizados por Salgado são ou possuem a ideia de fundir, integrar, incorporar.

A título de exemplificação, no Manifesto de Outubro de 1932, documento fundador da AIB, que expõe de maneira sucinta o programa do integralismo, conforme já fora citado, sendo válido repisar:

O cosmopolitismo, isto é, a influência estrangeira, é um mal de morte para o Nacionalismo. Combatê-lo é o nosso dever. E isso não quer dizer má vontade para com as Nações amigas, para com os filhos de outros paizes, que aqui trabalham para o engrandecimento da Nação Brasileira (Salgado, 1932, p. 3).

Neste ponto, por trás de uma suposta hospitalidade, há o tratamento meramente utilitarista para com os "filhos das Nações amigas", onde estes são bem vindos desde que contribuam para "O engrandecimento da Nação Brasileira”. A fé católica de Plínio Salgado esbarra em seu nacionalismo ao 
passo que o nacionalismo é influenciado pela fé católica. Ao designar o imigrante, ainda no trecho utilizado de Geografia Sentimental, o chefe da AIB faz uso da palavra fundir não por acaso. Não há intenção alguma por parte do Sigma, em preservar, ou respeitar culturas estrangeiras no Estado Integral.

O imigrante ocuparia sempre posição submissa e passiva diante da aculturação impelida pelo Estado Integral. Outro possível eixo de perspectiva, a partir do discurso ideológico de formação da "Raça Harmoniosa", a iniciar pelo Brasil e se alastrar para todo o continente americano ${ }^{14}$ em uma fusão étnica, é o ocultamento de uma possível política expansionista no continente, semelhante à "Teoria do Espaço Vital” desenvolvida e posta em prática por Hitler. Porém no integralismo, seria utilizado inicialmente meios não belicosos, e sim através da incorporação e miscigenação.

Como projeto para a implantação dos "Estados Integralistas" - aqueles que segundo Salgado se formariam na Quarta Humanidade - para toda a América do Sul, o líder da AIB descreve um cenário onde o interesse estacionaria na unidade econômica e moral, a partir da eliminação das barreiras alfandegárias e promoção do que Plínio chama de "intercâmbio cultural e espiritual". Na obra $A$ Quarta Humanidade, tem-se que:

A implantação do Estado Integral em cada uma das nações do Continente, será o primeiro passo que temos de dar em conjunto. Esse movimento, que se iniciou no Brasil, deverá estender-se pelos países sul-americanos. A suspensão de todas as barreiras alfandegárias entre esses povos e o mais íntimo intercâmbio cultural e espiritual devem ser preocupação imediata dos estados Integralistas Sul-

\footnotetext{
14 “(...) ó integralista do Brasil, que deveis acender a chama verde no Continente Americano, podeis dizer: 'Aristóteles, pensou para nós; Cristo deu-nos alma; César e Napoleão foram nosso precursores; Simão Bolívar o nosso anunciador; a América é nosso Império; e nós somos aquêle povo longamente esperado e que inicia, quase imperceptívelmente, a sua entrada nas Eras Humanas, porque o astro do nosso destino resplandeceu no céu"' SALGADO, Plínio. O Último Ocidente. in. Palavra Nova detempos Novos. op. cit. p. 290.
} 
Americanos. Com essa sólida estrutura econômica e moral, poderemos nós, povos escravizados, erguer a cabeça e solucionar conjuntamente as nossas insolvabilidades, a nossa situação de tributários explorados pelo Super-Capitalismo anticristão (Salgado, 1957, p. 74-75).

É interessante perceber, dentre as influências do integralismo para com os fascismos, a importância que a propaganda e a imprensa ocupam, podendo generalizar como característica comuns dos regimes e movimentos que se pretendem totalitários. É observado em ambas as ideologias reservam lugares de destaque na função desta para a perpetuação do movimento e sucesso político do mesmo. Segundo Arendt :

Por existirem num mundo não totalitário, os movimentos totalitários são forçados a recorrer ao que comumente chamamos de propaganda. Mas essa propaganda é sempre dirigida a um público de fora - sejam as camadas nãototalitárias da população do próprio país, sejam os países não-totalitários do exterior. (...) a propaganda totalitária pode ainda dirigir-se àqueles segmentos da própria população cuja coordenação não foi seguida de doutrinação suficiente (Arendt, 1989, p. 391).

Salgado apresenta o papel ocupado pela imprensa e a importância da mesma em Despertemos a Nação!. Esta obra possui relevo semelhante à Psicologia da Revolução, ambas com o intuito pedagógico e formador das elites para o integralismo. Em Despertemos a Nação! o líder da AIB reserva um capítulo de nome $A$ Missão da Imprensa, onde entende que os meios de divulgação de informações, têm como objetivo principal a doutrinação da massa no intuito de evitar a desordem. A imprensa no integralismo cumpria a função de propagar a doutrina do Sigma ao passo que realizasse a massificação de seus receptores. Os meios de divulgação da informação eram submetidos ao aparelho de censura da AIB, o Departamento de Propaganda, o que significa 
que a propaganda e a informações pertenciam ao mesmo conjunto para o integralismo. Neste sentido, o Departamento de Propaganda (O Monitor Integralista. Primeira quinzena de Maio de 1934. Arquivo Público e Histórico de Rio Claro-SP- Fundo Plínio Salgado: cx 131.021-131.038) possuía diretrizes rígidas e centralizadas, que emanavam da chefia nacional, ocupada por Plínio Salgado, e se espraiava para as demais Províncias. Algumas das incumbências geridas, que explicitam a pouca flexibilidade e o grau de controle do diretório central para seus núcleos regionais são:

1 - transmitir às Províncias as ordens e directivas do Chefe Nacional;

2 - fiscalizar e orientar as actividades dos Departamentos Provinciaes;

(...)

5 - nomear, dirigir e exonerar, de accordo com a chefia nacional os auxiliares do secretariado (Arquivo Público e Histórico de Rio Claro-SP- Fundo Plínio Salgado: cx 131.021-131.038).

Tanto a imprensa quanto a propaganda tomavam igual atenção especial dos fascismos alemão e italiano. São conhecidos os esforços de Mussolini em proporcionar a impressão de modernidade e modernização da Itália fascista, através da popularização das salas de cinema, e a criação do estúdio de cinema do Estado, o Cinecittà sob o lema de "o cinema é a arma mais forte". Para Hitler, em exame das causas da derrota alemã na I Guerra Mundial, a justificativa para a derrocada se iniciava na veiculação de propaganda de forma equivocada, por subestimar o inimigo.

Por exemplo, foi um erro fundamental querer tornar o inimigo ridículo, como o fizeram os jornais humorísticos austríacos e alemães.

Esse sistema é profundamente errado, pois o soldado, quando caía na realidade, fazia do inimigo idéia totalmente diferente, 
o que como era de esperar, acarretou graves consequências (Hitler, 2001, 136).

A propaganda, juntamente ao terror é essencial para os fascismos, tendo como objetivo a perpetuação e divulgação teórica, com amplos estudos, para alcançar ao maior amplitude possível. O esforço era para que a ideia inscrita no suporte se fizesse compreendida da maneira mais homogênea possível, buscando a massificação comportamental do público alvo, e a previsibilidade de suas ações.

Conforme foi visto, o integralismo reserva grande similaridade em relação aos fascismos, contudo, as características da teoria de Plínio Salgado não se esgotam apenas na análise comparativa com os movimentos de Hitler e Mussolini. É necessário transcender o Fascismo para que se possa alcançar a genealogia integralista elaborada por Salgado, da forma mais completa possível.

Assim, a pesquisa entende Salgado como portador de críticas ao seu contexto político e sociocultural. O líder da AIB, neste sentido, possuía ambições de promover a emergência de uma "nova cultura" para afastar a "crise do pensamento", que segundo Salgado, assolava o país, o que não implica em negar suas ambições autoritárias, implícitas nos rótulos apresentados pelo chefe da AIB. Torna-se nítida e obvia esta constatação quando se depara com a aberta simpatia deste movimento à massificação do contingente analfabeto ${ }^{15}$ e ao elitismo hierarquizado, ao que toca à "restauração do primado do Espírito, da Inteligência e da Verdade”. (Salgado, 1955d: p. 9)

Para atingir sua reforma no pensamento, não era, em absoluto, repulsiva para Salgado a ideia de cooptar experiências que se sobressaíram quanto à tomada do poder, e pudessem demonstrar certa coerência em conjunto, em relação às ambições do movimento. Neste leque de opções dispostas à AIB, se encontram os Fascismos, com maior ênfase ao italiano. Mas não houve apenas esta ideologia como viés de escolha a ser apropriado como discurso e ação. O Fascismo era apenas a mais famosa das teorias e modos de operação,

15 "O analfabetismo seria até um elemento positivo, porque representaria a massa bruta, facilmente dirigida pelas elites cultas” (SALGADO, Plínio. Despertemos a Nação, In. Obras Completas. v. 10. São Paulo: Editora das Américas, 1955e. p. 145, grifo meu).

Temáticas, Campinas, 20(39): 145-180, jan./jul. 2012 
porém não a única, dentre o arcabouço integralista.

É válido recuperar que os Estados positivistas contavam em número de três, havendo muitas semelhanças entre a literatura de Comte com as Humanidades de Salgado. Portanto, o fascismo é transcendido com larga adoção do positivismo por Plínio Salgado, porém, tal como o fascismo, a apropriação é feita de forma velada. No entanto, em virtude da maior popularidade e banalização de alguns conceitos do fascismo, este é encontrado com maior facilidade em meio à ideologia do sigma que o positivismo.

Outro aspecto na teoria do Sigma, que dialoga diretamente com o positivismo, é a extrema preocupação que Plínio expressa em seu pensamento conservador, pela manutenção da ordem, se manifestando em diversas instâncias, o que concomitantemente acarreta no elitismo, chegando o integralismo a desenvolver centros de formação das elites, organizados pelos departamentos de Estudos (Cavalari, 1990: pp. 47-49). Outras mais características apontam para aspectos que excedem a captação de influências como monopólio dos fascismos.

Por exemplo, conforme criticado no modelo de Paxton, nesta pesquisa, onde o autor apresenta 9 elementos que mobilizam a emergência dos fascismos de um modo geral, há alguns quesitos que não se encaixam no integralismo. Sendo este um modelo que se pretende geral e com tendências universalizantes, todos os pontos deveriam abranger o objeto a ser analisado, para que assim possamos classificá-lo de Fascista ou não. Portanto, estando a ideologia de Plínio Salgado, ao contrário do apresentado pelo próprio Robert Paxton, fora deste grupo segundo a classificação, diante da não abrangência do integralismo naquelas circunstâncias. O integralismo de Salgado também propõe a formação de uma raça superior - a "Raça Cósmica" ou "Raça Harmoniosa" - mas a partir da fusão, ao contrário dos exemplos apresentados, de todos os povos, conforme pode ser observado no trecho retirado de AQuartaHumanidade:

A raça brasileira e, de um modo geral, a sulamenricana, tem um sentido cósmico originado das fontes étnicas. Cumpre observar que as ondas imigratórias arianas e semitas, que se espraiam em nosso continente, não alteram a fisionomia 
profunda a alma americana. Assim como existe um meio físico, existe um meio étnico imperativo. (Salgado, 1957, p.: 66)

Nesta perspectiva, o integralismo é muito mais próximo do "bárbaro tecnizado" de Oswald Andrade, e de seu antecessor, o partido verde-amarelo e o Anta, pertencentes à heterogênea corrente modernista que assistiu sua projeção na Semana de Arte Moderna em 1922, que dos fascismos, ou de uma definição fechada de Fascismo.

\section{BIBLIOGRAFIA}

ADORNO, Theodor \& HORKHEIMER, Max. Dialética do Esclarecimento: fragmentos filosóficos. Rio de Janeiro: Jorge Zahar Editor, 1985.

ARENDT, H. Origens do totalitarismo. Tradução de Roberto Raposo. São Paulo: Companhia das Letras, 1989.

BENDIX, R. Construção Nacionale Cidadania. São Paulo: EDUSP,1996.

BENES, Edvard. Democracia de Hoje e de Amanhã. Tradução de Jiri Reiszman. Rio de Janeiro: Editôra Calvino, 1945.

BERTONHA, J.F. Sobo signo do fascio: o fascismo, os imigrantes e o Brasil, 19221943. São Paulo: Tese de doutoramento apresentada ao Departamento de História (IFCH/UNICAMP), 1998.

CAVALARI, Rosa Maria Feiteiro. Integralismo: ideologiaeorganização de umpartido de massa no Brasil(1932-1937). Bauru, SP: EDUSC, 1990. pp. 47 a 49.

DELGADO,I.G. Trajetóriae Contra-Reforma da Política Brasileira.in. SALGADO, Gilberto (org.). Cultura e instituiçôes sociais. Juiz de Fora: Ed. UFJF,2006.

FARIA, Carlos Aurélio Pimenta de. Uma Genealogia das Teorias e Modelos do EstadodeBem-EstarSocial. in Revista Brasileira de Informação Bibliográfica em Ciências sociais. Rio de Janeiro: Relumé-Dumará/ ANPOCS, 1998. 
ESPING-ANDERSEN, Gosta. As três Economias politicas do Welfare State. In. Lua Nova: Revista de cultura e política. OPresidencialismo em questão E Welfare State e Experiências Neoliberais. São Paulo: Centro de Estudos de cultura contemporânea. 1991.

GRAMSCI, A. El "Risorgimento”. Buenos Aires: Granica, 1974.

GINZBURG, Carlo. Mitologia Germânica: sobre um velho livro de Geórges Dumézil. In: . Mitos, Emblemas, Sinais: morfologia e história. São Paulo: Companhia das Letras, 1989.

HITLER, Adolf. Minha Luta. Tradução de Klaus Von Puschen. São Paulo: Centauro, 2001.

KONDER, L. Introdução ao Fascismo. 3 ed. Rio de Janeiro: Graal, 1977.

MARSHALL, T.H., Política Social. Rio de Janeiro Zahar editores, 1967.

MOORE, B. Poderpolítico e teoria social: sete estudos. São Paulo: Cultrix,1972.

. As Origens Sociais da Ditadura e da Democracia: senhores ecamponeses na construção do mundo moderno. Tradução de Maria Ludovina F. Couto. SãoPaulo: Martins Fontes, 1983.

NEUMANN, F. Estado Democrático e Estado Autoritário. Rio de Janeiro: Jorge Zahar, 1969.

O’DONNELL, G. Análise do Autoritarismo Burocrático. Tradução de Cláudia Shilling. Rio de Janeiro: Paz e Terra, 1990.

PAXTON, R. Anatomia do Fascismo. Tradução de Patrícia Zimbres e Paula Zimbres. São Paulo: Paz e Terra, 2007.

MOTTA, R.P.S.Em Guarda Contra operigo Vermelho: o anticomunismono Brasil (1917-1964). São Paulo: Perspectiva: FAPESP, 2002.

ROUX, G. Organização do Estado Novo Italiano(Estudo de Direito Político). São Paulo: Saraiva \& Cia. Editores, 1937.

SALGADO, P.Manifesto de Outubro de 1932. Secretaria Nacional de Propaganda, 1932. 
. O Nosso Brasil. Obras Completas. São Paulo. Editôra das Américas, 1954.

. A Quarta Humanidade. In. Obras Completas. São Paulo: Editora das Américas, 1957.

. In. Primeiro, Cristo! In. Obras Completas. v. 6. São Paulo: Editôra das Américas, 1955.

SALGADO, P. Palavras Novas dos Tempos Novos. in. Obras Completas. v. 7. São Paulo: Editora das Américas, 1955a.

. O Esperado. in. Obras Completas. v. 7. São Paulo: Editora das Américas, 1955b.

. Páginas de Ontem.in. Obras Completas. v. 10. São Paulo: Editôra das Américas, 1955c.

. Psicologia da Revolução. In. Obras Completas. v. 7. São Paulo: Editôra das Américas, 1955d.

. Geografia Sentimental. In. Obras completas. v. 4. São Paulo: Editôra das Américas, 1955d.

SALGADO, Plínio. Despertemos a Nação.in. Obras Completas. v. 10. São paulo: Editora das Américas, 1955e.

SPEER, A. Por dentro do III Reich: A derrocada. $3^{a}$ ed. Rio de Janeiro: Artenova, 1971.

RICOEUR, Paul. Interpretação e ideologias. Rio de Janeiro: Livraria Francisco Alves Editora S/A., 1983.

VASCONCELOS, José. La Raza Cósmica: mission de la raza iberoamericana. $10^{a}$ ed. México. D. F. Espasa - Calpe Mexicana S. A., 1986.

\section{ARQUIVO CONSULTADO}

Arquivo Público e Histórico de Rio Claro-SP - Fundo Plínio Salgado: cx. 003.007.002 